\title{
Taxonomy "under construction": advances in the systematics of Apocynaceae, with emphasis on the Brazilian Asclepiadoideae
}

\author{
Taxonomia "em obras": avanços na sistemática de Apocynaceae, \\ com ênfase nas Asclepiadoideae brasileiras
}

\author{
Alessandro Rapini ${ }^{1}$
}

\begin{abstract}
The Apocynaceae comprise approximately 5,000 species and are widely distributed. The family belongs to the Gentianales and can be easily recognized by the presence of latex and a style-head derived from the fusion of two carpels at the apex of the styles. The largest subfamily in Apocynaceae is Asclepiadoideae. Treated as the Asclepiadaceae for almost two centuries, it comprises about 3,000 species and is defined by stamens with bisporangiate anthers and pollen transferred in specialized units called pollinaria. Since the $19^{\text {th }}$ century, floristic studies and taxonomic monographs have significantly contributed to the taxonomy of Brazilian Asclepiadoideae. Nevertheless, advances in understanding the internal relationships in the subfamily were not done until this millennium, with the popularization of phylogenetic studies based on molecular data and powerful computer analyses. Advances in the systematics of Apocynaceae have provided new interpretations on the morphological evolution and biogeography of the family and have led to important changes in its classification. Nevertheless, several taxonomic rearrangements are still needed and it can be said that the taxonomy of Apocynaceae is "under construction". In this article, the major taxonomic changes in the family are reviewed, with special attention given to the systematics of Neotropical groups. A cladogram of the Apocynaceae is presented, which highlights the phylogenetic position of the Brazilian genera and their diversity in number of native species. The main studies and the diversity of Asclepiadoideae in Brazil are summarized and perspectives for future research on the subfamily are presented.
\end{abstract}

Key words: Asclepiadaceae, Brazil, molecular data, morphological evolution, phylogeny.

\section{Resumo}

As Apocynaceae compreendem aproximadamente 5.000 espécies e estão amplamente distribuídas. Pertencem às Gentianales e podem ser facilmente reconhecidas pela presença de látex e por uma cabeça estilar derivada da fusão dos dois carpelos no ápice do estilete. Asclepiadoideae é a sua maior subfamília. Tratada por quase dois séculos em Asclepiadaceae, ela inclui aproximadamente 3.000 espécies e é definida pelos estames com anteras biesporangiadas e pólen transferido em unidades especializadas denominadas polinários. Desde o século XIX, trabalhos florísticos e revisões taxonômicas têm contribuído significativamente para a taxonomia das Asclepiadoideae no Brasil. No entanto, foi apenas a partir deste milênio que estudos filogenéticos, principalmente com base em dados moleculares e um arsenal robusto de análises computacionais, propiciaram avanços significativos para a compreensão das relações internas na subfamília. Avanços na sistemática de Apocynaceae têm gerado novas interpretações sobre evolução morfológica e biogeografia e promovido mudanças substanciais na classificação da família. Vários arranjos taxonômicos ainda são necessários e pode-se dizer que a taxonomia de Apocynaceae encontra-se "em obras". Neste artigo, são revisadas as principais mudanças taxonômicas na família, com atenção especial para a sistemática dos grupos neotropicais. É apresentado um cladograma das Apocynaceae salientando a posição filogenética dos gêneros brasileiros e sua diversidade em número de espécies nativas. Os principais estudos e a diversidade de Asclepiadoideae no Brasil são sintetizados e perspectivas para futuras pesquisas na subfamília são apresentadas.

Palavras-chave: Asclepiadaceae, Brasil, dados moleculares, evolução morfológica, filogenia.

\footnotetext{
${ }^{1}$ Universidade Estadual de Feira de Santana, Depto. Ciências Biológicas, Av. Universitária s/n, Novo Horizonte, 44036-900, Feira de Santana, BA, Brazil. rapinibot@yahoo.com.br
} 


\section{Introduction}

Apocynaceae belongs to the Gentianales, an order of (eu)Asteridae, with five families: Apocynaceae, Gelseminaceae, Gentianaceae, Loganiaceae, and Rubiaceae (APG III 2009). With about 5,000 species, it is one of the ten largest families of angiosperms, and also one of the most popular, due to the traditional widespread use of some of its species as ornamental plants (e.g., Allamanda cathartica L., Catharanthus roseus (L.) G. Don, Nerium oleander L., Plumeria rubra L., Thevetia peruviana (Pers.) K. Schum.). Several species are rich in chemical compounds (e.g., Rauvolfia spp.), others provide hardwood (e.g., Aspidosperma spp.), and only a few are fruit species (Couma rigida Müll. Arg., known as mucugê, and Hancornia speciosa Gomes, known as mangaba). They show variable habit, from magna trees to climbing vines or small herbs, including some succulent ones (Stapeliinae, paleotropical). Yet, they can be easily recognized by the presence of latex and by a bicarpelar gynoecium, in almost all cases separated at the ovary level, but distally merging to form an organ called the style-head. The carpels are usually separated at the apex, forming the apical appendices, sometimes inconspicuous. The lineage showed a gradual increase in the synorganization of the floral structures, leading to gynostegium formation, derived from the postgenital merging of the stamens to the style-head, and culminating in the formation of the pollinaria, specialized pollen units characteristic of the subfamilies Asclepiadoideae, Secamonoideae, and Periplocoideae (Rapini 2004).

Although it was initially recognized as "Apocyna" by Adanson, in 1763, Apocynaceae was formally established as "Apocineae" by Jussieu (1789), a work that marks the beginning of valid supra-specific names for spermatophytes (International Code of Botanical Nomenclature, Art. 13.1; McNeill et al. 2006). Subsequently, the group was divided by Brown (1810) into two families of similar sizes and easily distinguished by the presence (Asclepiadaceae s.l.) or absence (Apocynaceae s.str.) of pollinaria. Almost a century later, Schlechter (1905) subdivided Brown's Asclepiadaceae s.l. into two families, Periplocaceae (absent in the Neotropics), with spatulate pollinaria, and Asclepiadaceae s.str., with bifurcated pollinaria. A fourth alternative, considering Periplocaceae in Apocynaceae s.str., was also suggested, approximating it either to
Rauvolfioideae ("Plumerioideae"; Schumann 1895; Wanntorp 1988) or Apocynoideae (Nilsson et al. 1993). Despite these taxonomic divisions, the proximity between these groups has never been questioned, and when recognized, these families were frequently classified in a category immediately above, such as Rosatti's (1989) suborder Apocynineae.

With the diffusion of the phylogenetic principles for classification (e.g., Backlund \& Bremer 1998), and the perception that the differences between Asclepiadaceae and Apocynaceae s.str. represent arbitrary limits in the morphological gradation between these families (e.g., Safwat 1962; Endress \& Bruyns 2000), a broader concept came to be followed by most authors (e.g., APG III 2009; Reveal \& Chase 2011). The adoption of Apocynaceae $s$.l. rather than Asclepiadaceae is not the result of findings revealed only by molecular data, or generated only by computationally sophisticated phylogenetic analyses. More than that, this comprehensive circumscription portrays the change in the concept of taxonomic grouping adopted in botany, especially after the 1990s, and arises as a strategy so the paraphyletic group Apocynaceae s.str. does not have to be recognized (Goyder 1999; Rapini 2000).

This essay aims to synthesize the advances in the systematics of Apocynaceae, focusing mainly on phylogenetic studies and the incorporation of its results on the taxonomy of the family. Special attention will be given to studies on Asclepiadoideae and its implications for the systematics of Neotropical groups. Firstly, the general phylogenetic structure of Apocynaceae will be presented, showing the relationship among its main groups and discussing the main conceptual changes in the internal classification of the family. Once the position of Asclepiadoideae in Apocynaceae is contextualized, phylogenetic studies on the subfamily will be addressed, pointing out the most important advances in the taxonomy of the group. The recent monographic and floristic studies which assisted the compilation of the list containing almost 400 species of Asclepiadoideae of Brazil (Rapini et al. 2010a) are indicated, and perspectives for future taxonomic studies in the subfamily will be presented.

\section{Apocynaceae systematics}

Jussieu (1789) described Apocynaceae ("Apocineae") with 24 genera subdivided in three groups, essentially defined by fruit characteristics 
(berry-like or bifollicular) and seeds (with or without coma). Brown's (1810) contribution increased the number of genera to 53, and today they reach almost 400; the increase in the number of species in these last 200 years was even greater, leaping from 169 to more than 5,000 (Endress 2004). In the Neotropical Region, the family is represented by nearly 100 genera and 1,500 species (Rapini 2004), approximately $70 \%$ of the genera and half of these species being native to Brazil (Rapini et al. 2009; Koch \& Rapini 2011).

Five subfamilies are today included in Apocynaceae (e.g., Endress \& Bruyns 2000; Endress et al. 2007): Rauvolfioideae (cosmopolitan; 10 tribes/83 genera), Apocynoideae (cosmopolitan; 8 tribes/80 genera), Periplocoideae (Old World; 33 genera), Secamonoideae (Old World; 8 genera), and Asclepiadoideae (cosmopolitan; 4 tribes/172 genera); the first two subfamilies are paraphyletic, while the last three are monophyletic. Rauvolfioideae consists of the basal grade of the family, while Apocynoideae forms a more derived grade, from which Periplocoideae, Secamonoideae, and Asclepiadoideae emerge. Secamonoideae and Asclepiadoideae form a clade (Asclepiadaceae s.str.), but the position of Periplocoideae is uncertain. This last subfamily has appeared in different positions in the APSA clade, which includes Apocynoideae, Periplocoideae, Secamonoideae, and Asclepiadoideae, but its proximity to "Asclepiadaceae s.str." is unlikely, since Secamonoideae and Asclepiadoideae seem to be more closely related to the African tribe Baisseeae of Apocynoideae (Sennblad \& Bremer 1996, 2000, 2002; Sennblad et al. 1998; Potgieter \& Albert 2001; Livshultz et al. 2007; Simões et al. 2007; Livshultz 2010; Fig. 1).

The use of molecular data in phylogenetic analyses of Apocynaceae (e.g., Potgieter \& Albert 2001; Simões et al. 2007) was crucial to reveal the artificiality of many Rauvolfioideae tribes traditionally defined based on fruit and seed morphology. The gynoecium, free at the ovary level, emerged as a synapomorphy of Apocynaceae, derived from the syncarpy that characterizes the other Gentianales. This interpretation was confirmed by the positions of Aspidospermeae and Alstonieae, together forming the basal grade of Apocynaceae (Simões et al. 2007). The congenital syncarpy of the ovary is a derived and homoplastic condition, and not a symplesiomorphy of the family. Similarly, the fleshy and indehiscent fruits arised many times in the evolution of Apocynaceae (Potgieter \& Albert 2001; Simões et al. 2007). Taxonomically, these findings had direct impact on the circumscription of Carisseae (sensu Leeuwenberg 1994), leading to its disintegration in four tribes (Carisseae s.str., Hunterieae, Melodineae, and Willughbeieae; Endress et al. 2007). Carisseae, traditionally regarded as the most basal tribe of Apocynaceae s.str., was reduced to two genera only, Acokanthera G. Don and Carissa L., and began to be recognized as the most derived tribe (Carisseae s.str.) of Rauvolfioideae, raising as sister group of the APSA clade. Among the three tribes segregated from Carisseae s.l., only Willughbeieae has representatives in the New World. It appears in a clade with Vinceae and Tabernaemontanae (divided into Tabernaemontaninae and Ambelaniinae; Simões et al. 2010), both also having representatives in the New World as well as in the Old World (for a general description of these relationships, please see Fig. 1).

Although fruits and seeds vary amongst the members of Rauvolfioideae, they are conservative in the APSA clade, which helps to define the lineage morphologically. The group has been recognized by the presence of bifollicular fruits and comose seeds since Jussieu (1789), although these characteristics appear independently in groups of Rauvolfioideae, such as bifollicular fruits in Plumerieae and Vinceae and comose seeds in Alstonieae. Other diagnostic characteristics have also been pointed out to define the APSA clade, such as corolla with dextrorse prefoliation, lignified and partially sterile anthers, gynostegium formation, porate pollen grains, and production of cardenolides and steroidal (but not indole) alkaloids (Livshultz et al. 2007, and references cited). Wrightieae (sensu Leeuwenberg 1994) traditionally considered as the most basal tribe of Apocynoideae, was found to be paraphyletic (Sennblad \& Bremer 1996; Sennblad et al. 1998), and most of its genera were distributed in Wrightieae s.str. (reduced to three genera only), Nerieae, and Malouetieae (Endress et al. 2007), three tribes that form together the basal grade of APSA. Wrightieae s.str. is the most basal tribe of the APSA clade, which is coherent with the retention of some plesiomorphies in the group, such as sinistrorse prefoliation and seeds with chalazal coma only, being dextrorse prefoliation and micropylar coma probably synapomorphies of its sister group. Except for this grade, the APSA 

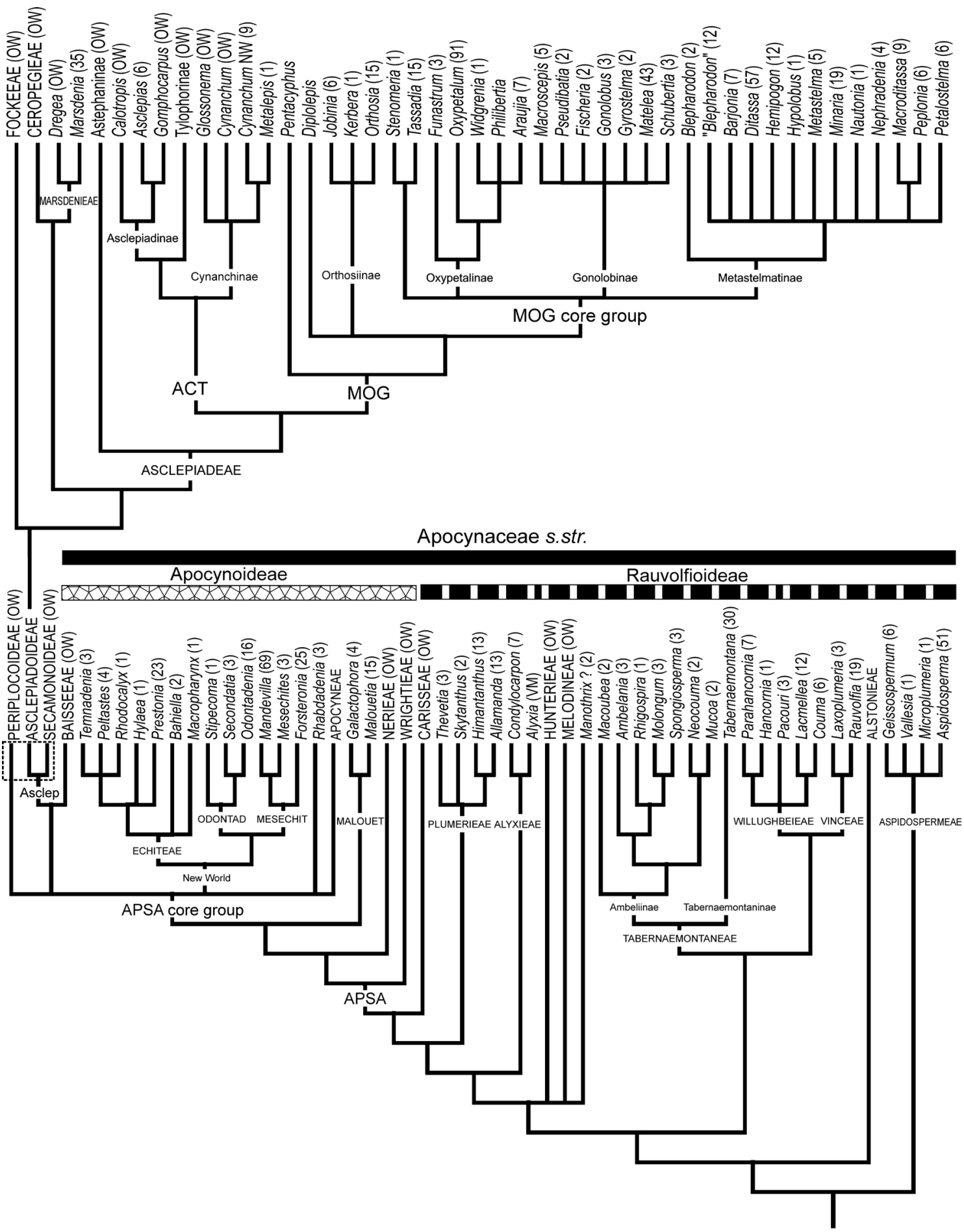

Figure 1 - Reconstructed phylogenetic hypothesis based on the studies discussed in this work. Terminals represented in Brazil are at genus level (except Asclepiadoideae, which is presented in detail above), with the number of species (Koch \& Rapini 2011) between paretentheses. Names of tribes and subfamilies are in capital letters. The traced rectangle shows the Asclepiadaceae s.l.; ACT (Asclepiadinae, Cynanchinae, and Tylophorinae), APSA (Apocynoideae, Periplocoideae, Secamonoideae, and Asclepiadoideae), Asclep (Asclepiadaceae s.str.), MALOUET (Malouetieae), MESECHIT (Mesechiteae), MOG (Metastelmatinae, Oxypetalinae, and Gonolobinae), ODONTAD (Odontadenieae), OW (Old World). The position of Manothryx is uncertain among lineages and tribes of the Rauvolfioideae grade. 
core group can be divided into six main lineages: 1) Apocyneae, an essentially Asian tribe, but including the North American genus Apocynum L.; 2) Rhabdadenia Müll. Arg., a Neotropical genus; 3) a clade including Echiteae, Odontadenieae, and Mesechiteae, predominantly from the New World, but with a relatively recent dispersion to the Old World; 4) Baisseeae, an African tribe; 5) "Asclepiadaceae s.str.", forming a clade with Baisseeae; and, 6) Periplocoideae, a subfamily exclusive to the Old World (Livshultz et al. 2007; Livshultz 2010; Fig. 1).

The relationships in the clade of the New World (clade 3 above) were investigated in more detail for the tribe Mesechiteae (Simões et al. 2004, 2006), which led to significant modifications in its circumscription: Secondatia A. DC. and Galactophora Woodson were excluded, the first being transferred to Odontadenieae, and the second to Malouetieae, while Forsteronia G. Mey., previously in Apocyneae, was incorporated into Mesechiteae (Endress et al. 2007). The tribe came to be recognized by the colleters on the adaxial side of the leaf, cordate to truncate anthers, style-head with five longitudinal ribs and cellular fusion of anthers to the style-head (Simões et al., 2004). Its largest genus, Mandevilla Lindl. (120 species), was extended to include the South American genera Macrosiphonia Müll. Arg. and Quiotania Zarucchi, and the North American genera Telosiphonia (Woodson) Henrickson. As they are both (sub)shrubs, with woolly leaves and white flowers with a long, narrow tube, Macrosiphonia and Telosiphonia, in spite of being geographically apart, had been considered as co-generic by Woodson (1933). Analyses with molecular data, however, have shown that these groups correspond to lineages that appeared independently within Mandevilla, representing a fine example of convergence, possibly associated with the occupation of open, dry habitas and hawkmoth pollination (Simões et al. 2006).

\section{Asclepiadoideae}

Asclepiadoideae represents the largest APSA clade. The subfamily includes about 3,000 species and 170 genera, representing an extremely successful lineage when compared to its sister group Secamonoideae, with only 180 species and eight genera (Meve 2002; Endress et al. 2007). Five tribes were recognized by Liede \& Albers (1994) in Asclepiadoideae: Fockeeae (Old
World), Asclepiadeae (cosmopolitan), Gonolobeae (New World; presently, Gonolobinae, subtribe of Asclepiadeae), Marsdenieae (cosmopolitan), and Stapelieae (Old World; currently Ceropegieae). Subsequently, the Asclepiadeae genera were classified into five subtribes (Liede 1997a): Astephanineae (paleotropical), Asclepiadineae (cosmopolitan), Glossonematineae (Paleotropical), Oxypetalinae (Neotropical), and Gonolobinae (Neotropical), establishing an updated database for a more objective evaluation of the taxonomy of the group. Based on the phylogenetic results, especially with molecular data, it was found that some of these subtribes were not monophyletic (for a comparison between the pre-cladistc classifications and the first phylogenetic results in the subfamily, see Rapini et al. 2003). The incorporation of these new findings in the taxonomy of Asclepiadoiadeae required a number of rearrangements, producing a classification with eight subtribes (Endress et al. 2007). The subtribe Tylophorinae was created, consisting of nine genera, most of them taken from Astephanineae, which was reduced to only three genera. Metastelmatinae, which presented a wide distribution and included more than 30 genera, is now restricted to 14 American genera; the rest of the subtribe was mostly segregated to compose Cynanchinae. Glossonematinae was also included in Cynanchinae, forming a subtribe predominantly from the Old World, with 14 genera. Finally, Orthosiineae was created from three American genera, also segregated from Metastelmatinae.

The first phylogenetic analyses including Asclepiadoideae focused mainly on the relationships among the subfamilies of Apocynaceae (discussed in the Introduction). Few representatives of the group were sampled, and as a consequence, the results were of limited scope for internal relationships in Asclepiadoideae. More representative analyses of the subfamily were carried out with morphological data focused mainly on groups of the Old World (Liede 1994, 1996a, 1997b). Until the 1990s, the taxonomic studies carried out in the Americas had primarily focused on elaborating a classification system for identification at the species level, and many genera were defined artificially, especially based on corona morphology and/or on the type of inflorescence (Rapini 2002). The first study that broke away from that taxonomic pragmatism in Brazil was carried out with the species from the Espinhaço Range, in the state of Minas Gerais (Rapini et al. 2001). Albeit without objective 
phylogenetic analyses, groups were limited based on morphological affinities which supposedly would reflect phylogenetic relationships, and therefore, represented grouping hypotheses that could be evaluated from a cladistic point of view. In less than 10 years, however, about $25 \%$ of the species from that survey have already had their classification changed, and approximately $10 \%$ of the species found in the whole Espinhaço Range, in Minas Gerais and Bahia states, are still in need of taxonomic modifications, waiting for more accurate phylogenetic results to direct them (Rapini 2010a).

Neotropical groups were given more significant representation in phylogenetic studies with the popularization of phylogenetic analyses with molecular data. The plastid markers $r b c \mathrm{~L}$, $m a t K$, and $t r n \mathrm{~L}-\mathrm{F}$ ( $t r n \mathrm{~L}$ intron and $t r n \mathrm{~L}-\mathrm{F}$ intergenic spacer) were the most used at this stage, and the first truly representative phylogenetic analysis of the Neotropical groups (65 species and 26 genera) used only the last one (Rapini et al. 2003; see also for a list of the first phylogenetic studies in the subfamily). This study was followed by one (LiedeSchumann et al. 2005) including trnT-F (trnT-L and $t r n \mathrm{~L}-\mathrm{F}$ spacers with the $t r n \mathrm{~L}$ intron between them) and rps16, and another one (Rapini et al. 2006) including trn T-L, rps 16, matK, and trnS-G regions. The reason for this preference for plastid markers is simple: the most used nuclear markers for phylogenetic studies of plants (e.g., ITS, but also $L E A F Y$ ) present polymorphic paralogs in many Neotropical species of Asclepiadoideae, requiring cloning (Rapini et al. 2006; Krings et al. 2008). The nuclear ribosomal DNA ITS, for instance, is easily amplified and presents high substitution rates in Asclepiadoideae, so it is appropriate for analyses at the genus level. However, the recurring presence of polymorphisms in this marker puts its phylogenetic information in doubt, as its phylogeny may not reflect that of the detainers, leading to distorted conclusions about relationships in the group (Alvarez \& Wendel 2003; Feliner \& Rosselló 2007).

Today, it is possible to have a more consistent view of the phylogenetic structure of Asclepiadoideae and understand the position of the Neotropical groups in this context. Fockeeae is the most basal tribe of the subfamily, including only two genera of the Old World, Fockea Endl. and Cibirhiza Bruyns. Its position is justified by pollinaria morphology: absence of caudicles (or very reduced ones), pollinia with no external wall, and pollen in tetrads, characteristics considered to be intermediate between Secamonoideae and Asclepiadoideae (Kunze et al. 1994; Endress \& Bruyns 2000; Endress \& Stevens 2001). This relationship has also been confirmed in phylogenetic studies with molecular data (e.g., Sennblad \& Bremer 2000, 2002; Fishbein 2001; Potgieter \& Albert 2001; Rapini et al. 2003; Lahaye et al. 2007). The other Asclepiadoideae plants are divided into two clades basically defined by the position of the pollinia: Asclepiadeae (cosmopolitan), with pendent pollinia, and a clade with erect pollinia, consisted of Ceropegieae (Old World only) and Marsdenieae (cosmopolitan). Although species in Tylophorinae and Gonolobinae show horizontal pollinia, which may be interpreted as an intermediate between Asclepiadeae and Marsdenieae, the position of these groups in Asclepiadeae has been confirmed based on molecular data (Liede et al. 2002; Rapini et al. 2003; Liede-Schumann et al. 2005). In the clade with erect pollinia, only Ceropegieae is divided into subtribes: Anisotominae, Heterostemminae, Leptadeniinae, and Stapeliinae (Endress et al. 2007), which is supported by phylogenetic results with trnT-F data (Meve \& Liede 2004). In Asclepiadeae, Astephaninae is the most basal subtribe; the remainder of the tribe can be divided into two clades: one exclusively from the New World, predominantly consisting of representatives of the subtribes Metastelmatinae, Oxypetalinae, and Gonolobinae (Clade MOG), and the other predominantly from the Old World, consisting of the subtribes Asclepiadinae, Cynanchinae, and Tylophorinae (Clade ACT) (Rapini et al. 2003; Fig. 1).

\section{Asclepiadoideae of the New World}

The Neotropical species of Asclepiadoideae are divided into four main lineages, which reached the New World at different moments and probably by different routes (Rapini et al. 2007). The clade MOG seems to have colonized the Americas by transoceanic dispersion, from Africa to South America, and it is the oldest and also the largest lineage in the Americas, including about 750 species. Besides the three subtribes that form the MOG core group, the clade includes Orthosiinae and the genera Diplolepis R. Br. (Argentina and Chile) and Pentacyphus Schltr. (Colombia, Ecuador, and Peru), the last one being its most basal genus (Liede-Schumann et al. 2005). The relationship between Diplolepis, Orthosiinae, and the MOG core group is not settled (Liede-Schumann et al. 2005; Hechem et al. 2011) and, in the core 
group, the relationship between Metastelmatinae, Oxypetalinae, and Gonolobinae, and the position of Tassadia Decne. (together with Stenomeria Turcz.) among them is also uncertain (Liede-Schumann et al. 2005; Rapini et al. 2006; Fig. 1).

The second lineage of Asclepiadoideae to arrive in the New World was Cynanchum L. subgenus Melichampia (A. Gray) Woodson. It belongs to Cynanchinae, and is placed in a clade which is predominantly from the Old World. It has only 23 species and is divided into two main clades, one predominantly South-American (section Roulinia (Decne.) Sundell) and the other North-American (section Mellichampia (A. Gray) Sundell), both showing relatively slow diversification (Rapini et al. 2007). The third lineage to colonize the New World was Asclepias L. The genus includes about 125 species (Woodson 1954), considering only the American ones, and most of them are concentrated in North America. The lineage is placed in a predominantly African clade of Asclepiadinae (Goyder et al. 2007), from which it would have emerged, possibly reaching North America via the Bering Strait (Rapini et al. 2007). The last lineage to come into the New World was Marsdenia R. Br. It has about 70 Neotropical species and forms a clade nested in the Paleotropical Mardenieae (e.g. Rapini et al. 2003). This is the only Asclepiadoideae lineage with erect pollinia in the Americas, where it was marked by rapid diversification (Rapini et al. 2007).

MOG is certainly the most interesting and promising clade for students of the Asclepiadoideae in the Neotropics. It belongs exclusively to the New World, has a huge diversity, and its internal relationships are complex, hard to define based on morphological or molecular characteristics. Most of the new findings provided by recent phylogenetic studies on the subfamily are directly related to the circumscription of Metastelmatinae. The delimitation of Sarcostemma R. Br. is a good example of how difficult it is to recover historical relationships among the members of MOG. Holm (1950) has adopted a Pantropical concept for the genus, including the American genera Cystostemma E. Fourn., Funastrum E. Fourn., Pentacyphus, and Philibertia Kunth in its synonymy. In spite of the fragility of the first phylogenetic studies, both with morphological (Liede 1996b) and molecular data (trnL-F; Liede \& Taüber 2000), it was clear that Sarcostemma, as it was delimited, would not be monophyletic. The species of the Old World are placed in a clade with Cynanchum and similar genera, while species of the New World form a paraphyletic group, justifying the recognition of different genera. Phylogenetic studies with more terminals and/or more molecular markers (e.g., Liede \& Taüber 2002; Rapini et al. 2003, 2006; Liede-Schumann et al. 2005) demonstrated that Sarcostemma species from the Old World emerge in Cynanchinae and, today, are placed in Cynanchum, while the American species belong to the MOG clade, Pentacyphus diverging right from its basis, and Funastrum and Philibertia appearing in Oxypetalinae, the first as a basal genus, and the second as a more derived genus in the subtribe (Fig. 1). Cystostemma, on the other hand, was regarded as a synonym of Funastrum (Cystostemma glandulosum E. Fourn. = Funastrum flavum (Decne.) Schltr.).

Phylogenetic studies (Liede-Schumann et al. 2005) have also demonstrated that the tribe Orthosieae consisted of five genera of Asclepiadeae, therefore the tribe category would not be appropriate for the taxon. Even worse, these genera are not closely related phylogenetically: Orthosia Decne. and Jobinia Müll. Arg. are not in the MOG core group and belong to the subtribe Orthosiineae, while Peplonia Decne. and Gonioanthela Malme form a clade in Metastelmatinae, being closely related to Macroditassa Malme (Silva 2010; Fig. 1). Peplonia was regarded as a monospecific genus due to its double corona, with the external segments merging almost to the apex, forming a tube. This characteristic of the genera highlighted an autapomorphy of the species and did not establish any phylogenetic relationship. The merger of Peplonia and Gonioanthela then resulted in a monophyletic taxon with six species distributed in the eastern part of Brazil, especially in the Atlantic Forest, and characterized by a twining habit and axilliary inflorescences, generally opposite (Rapini et al. 2004).

Another new taxonomic finding presented by phylogenetic studies on Asclepiadoideae was the creation of the genera Minaria T.U.P. Konno \& Rapini. Analyses with plastid markers (Rapini et al. 2006) have confirmed the existence of a clade consisted of subshrubs with very small leaves diverging at the initial evolution of Metastelmatinae. Most species are confined to small areas of "campos rupestres" in the Espinhaço Range, mainly in its Minas Gerais portion (Konno et al. 2006). Its 
subshrub habit must have persisted in association with the occupation of open habitats, while its floral plasticity may have evolved stochastically and/or associated with the diversity of available pollinators in small, isolated populations of the Espinhaço Range. Such combination of factors must have made Minaria become a lineage which can be recognized by vegetative characters, but is cryptic in relation to floral characters traditionally used in the taxonomy of the family, including species with double corona and even species without corona. Species previously classified in phylogenetically distant genera, such as Ditassa R. Br. (Metastelmatinae) and Astephanus R. Br. (Astephaninae), were included in this genus. Yet, the circumscription of Minaria is not complete, as Barjonia harleyi Fontella \& Marquete and Hemipogon harleyi (Fontella) Goyder, two species endemic to the Bahia portion of Espinhaço Range, are nested in species of Minaria from the Minas Gerais portion, and will also be transferred to this genus (Silva 2008, 2010). This relationship had already been suggested for B. harleyi (Konno et al. 2006), but it is surprising for $H$. harleyi, a rare species that is rather discrepant with the rest of the genus by having twining habit, linear leaves, and flowers with conspicuously rostrate gynostegium, which is why it was originally described in Melinia Decne. (= Philibertia, Oxypetalinae). Hemipogon harleyi affinities could only be detected from molecular studies, which once more proves the power of this data source and the sensitivity of the analyses in recovering the evolutionary history of plants.

The delimitation of many genera of the MOG clade is still being evaluated, and its taxonomy will still be considerably modified in order to clearly and accurately define the phylogenetic relationships among its members. Besides Ditassa, genus from which Minaria was segregated (although its circumscription will still be amended to a considerable extent), other genera have been shown inadequate from the phylogenetic systematics point of view: Blepharodon Decne. is an example. Blepharodon lineare (Decne.) Decne., the type species of the genus, appears as a sister group of the other Metastelmatinae, forming a clade with only B. ampliflorum E. Fourn. The other species from the genus ("Blepharodon"), however, appear in the Metastelmatinae core group; therefore, they will have to be transferred to another genus (or other genera) (Rapini et al. 2006; Rapini 2010a;
Silva 2010). Conflicts between phylogenetic results and taxonomic classification are not exclusive to Metastelmatinae. In Oxypetalinae, Schistogyne Hook. \& Arn. emerges in the Oxypetalum core group, while Morrenia Lindl. emerges amongst the species of Araujia Brot. (Liede-Schumann et al. 2005; Farinaccio 2007). In both cases, these relationships could be morphologically found, which supported the synonymies of Schistogyne and Morrenia in Oxypetalum and Araujia, respectively (Rapini et al. 2011). In Gonolobinae, the situation is more complex, and the relationships less resolved. The delimitation of Gonolobus Michx. was confirmed by molecular data, and the laminar dorsal appendix of the anthers seems to represent a synapomorphy of the genus (Krings et al. 2008), as originally defined by Woodson (1941). However, the circumscription of Matelea Aubl. remains obscure, perpetuating discussions on whether small genera synonymized in Matelea should be reestablished.

\section{Asclepiadoideae in Brazil}

South America is one of the main centres of Asclepiadoideae diversity, and Brazil emerges as one of the countries with the highest number of species of the subfamily in the Neotropics. Most of these species were described in the $19^{\text {th }}$ century, especially by Descaine (1844: 92 species) and Fournier (1885: 184 species). During the $20^{\text {th }}$ century, taxonomic studies on the group were basically dominated by two researchers, G.O.A. Malme, in the first half of the century, and J. Fontella Pereira, in the second. They were responsible for the description of several new species, but also recognized many synonyms, helping to stabilize the number of species in the group (Rapini et al. 2005). In the last five years, a subtribe (Orthosiinae; Liede-Schumann et al. 2005), a genus (Minaria; Konno et al. 2006), 10 species and more than 30 new combinations in the subfamily were proposed for Brazilian Asclepiadoideae, bringing together the knowledge of more than 10 researchers, Brazilian and foreign, which demonstrates a decentralization of the studies on the group. Many species are still being described, mainly in less explored areas, such as is the case of the Caatinga (e.g., Rapini \& FontellaPereira 2011).

Some genera represented in Brazil have synopses, taxonomic reviews or representative surveys for the country done in the last 50 years: 
Asclepias $^{1}$ (12 South-American species, including assumed hybrids; Bollwinckel 1969), Barjonia Decne. (5 species²; Marquete 1979), Blepharodon ${ }^{3}$ (7 species for Brazil; Fontella-Pereira \& Marquete 1973; and 11 species; Morillo 1976), Cynanchum ${ }^{4}$ (5 species, as "Telminostelma", in Fontella-Pereira \& Schwarz 1981; 11 species, as Cynanchum subgenus Mellichampia, in Sundell 1981), Ditassa (50 species for Brazil; Konno 2005), Fischeria DC. (6 species; Murphy 1986), Jobinia (5 species for Brazil; Schwarz \& Fontella-Pereira 1995), Macroditassa $^{5}$ (11 species for Brazil; FontellaPereira \& Ferreira, 2005), Minaria ${ }^{6}$ (19 species; Konno 2005; Konno et al. 2006), Morrenia (= Araujia, 8 species; Goyder 2003), Oxypetalum (124 South American species and 90 Brazilian species; Farinaccio 2007), Peplonia (6 species; Rapini et al. 2004), and Tassadia (17 species ${ }^{7}$; Fontella-Pereira 1977); finally, the review of Orthosia is in progress (about 40 species; Liede-Schumann \& Meve 2008). In the last decade, relatively comprehensive inventories (as "Asclepiadaceae" or as part of Apocynaceae s.l.) were also concluded, highlighting the floras of Cadeia do Espinhaço of Minas Gerais (99 species; Rapini et al. 2001), later also including the Bahia portion (133 species; Rapini 2010a; for pictures of most of this diversity, see Rapini 2010b), from Santa Catarina (51 species; Fontella-Pereira et al. 2004), from São Paulo (83 species; FontellaPereira 2005), and from Distrito Federal (40 species; Fontella-Pereira et al. 2003), besides the lists from the Northeast (65 species; Mezabarba et

\footnotetext{
${ }^{1}$ The genus is predominantly North American, but Goyder (2009) has adopted a more comprehensive circumscription, also including African species.

${ }^{2}$ Nowadays, $B$. chloraeifolia Decne. is not considered synonymous with $B$. erecta (Vell.) K. Schum., while $B$. harleyi, described after the review, shall be transferred to Minaria.

${ }^{3}$ This genus shall be reduced to only two species, $B$. lineare and $B$ ampliflorum (eventually considered synonymus; e.g., Morillo 1976).

${ }^{4}$ Some Neotropical species traditionally addressed in Cynanchum (Cynanchinae) belong to the clade MOG, as C. morrenioides Goyder, which emerges as a sister group of the other Orthosiinae and shall be treated as a monotypic genus (Liede \& Meve, under review), and many species recently transferred to Diplolepis (Hechem et al. 2011).

${ }^{5}$ Some species of the genus, including the type species, form a grade in relation to Peplonia, and the synonimization of Macroditassa under Peplonia is being proposed (Silva et al., under review).

${ }^{6}$ Barjonia harleyi and Hemipogon harleyi shall be transferred to this genus (Silva et al., under review).

${ }^{7}$ After the genus review, eight species have been incorporated to Tassadia, four new ones, including T. rizzoana Fontella, from Tocantins; Tassadia subulata (Vell.) Fontella \& E.A. Schwarz, however, was included in the synonymy of Orthosia scoparia (Nutt.) Liede \& Meve.
}

al. 2006), from Caatinga (67 species; Rapini 2006; this number has doubled; data under preparation) and from the Atlantic Forest (213 species; Rapini \& Fontella-Pereira 2009). The North Region possibly represents the largest gap in our knowledge of Brazilian flora, and with Asclepiadoideae, it is not different. Except for the catalogue of species from Acre (15 species only; Hansen et al. 2009), recent surveys in the region are scarce. The taxonomy of the group is even more difficult in the North because of its border with other countries, which increases the chance of having species shared with other different and little known floras, such as those from Colombia, Venezuela, and Bolivia.

In spite of the numerous gaps, the taxonomic and floristic advances achieved in the last decades have enabled the composition of a list of species of Asclepiadoideae from Brazil (Rapini et al. 2010a, updated in Koch \& Rapini 2011), bringing together 32 genera and 392 native species; Oxypetalum (91 species), Ditassa (57), Matelea (43), and Marsdenia (35) are the largest genera in number of species, while Kerbera E. Fourn. (K. eichleri E. Fourn.), Hypolobus E. Fourn. (H. infractus E. Fourn.), and Nautonia Decne. (N. nummularia Decne.) are monotypic (Fig. 1). This diversity represents $10 \%$ of the entire subfamily, and is much greater than that found in other megadiverse countries of Latin America, such as Peru (105 species; Brako \& Zarucchi 1993 ) and/or countries with great territorial extension, such as Argentina (145 species; Ezcurra 1999) and Mexico (288 species; Juárez-Jaimes et al. 2007).

Most of these species are endemic to Brazil, and many have quite limited distribution; at least one fifth of them ( 76 species) is restricted to areas of less than $10,000 \mathrm{~km}^{2}$ (Rapini et al. 2009). The Espinhaço Range, including the states of Minas Gerais and Bahia, stands out by having a great diversity of Asclepiadoideae, with high rates of endemism, especially in its Minas Gerais portion (Rapini et al. 2001, 2002; Rapini 2010a,b). A total of 133 species of Asclepiadoideae are registered in the Espinhaço Range, which corresponds to more than $30 \%$ of the species registered for Brazil, and about 30\% (42 species) of them are endemic, which corresponds to $10 \%$ of the Brazilian species of the subfamily (Rapini 2010a). Some species with sparse distribution had not been collected for more than a century. In Serra do Cipó, the collections of Minaria hemipogonoides (E. Fourn.) T.U.P. Konno \& Rapini, in 2008, and, especially, of Hemipogon abietoides E. Fourn., 
in 2007 and 2008, deserve special attention. Both species had not been collected for more than a century, and the latter species was known only from its type collection, collected by Riedel during the expedition led by Baron Langsdorff, who crossed the mountains of Lapinha in January 1825, returning from Diamantina (Rapini et al. 2010b). Also particularly noteworthy was the recent collection of Nephradenia filipes Malme from the steep walls of the canyons of Chapada dos Guimarães, in the state of Mato Grosso. The species, collected by Malme in 1894 and described by himself in 1900, was also known only from its type collection, and was rediscovered in 2009, next to Rauvolfia anomala Rapini \& Koch, a recently described species (Rapini et al. 2010c).

\section{Implications for Taxonomic Studies}

Most species of Apocynaceae were described in the 19th century, but until the 1990s, the taxonomy of the family did not reflect the phylogenetic relationships of its representatives. With the advent of cladistics and analyses statistically more robust, many inconsistencies between phylogenetic results and the taxonomy of Apocynaceae were evidenced. The use of molecular data, especially plastid makers, and more powerful methods to detect phylogenetic evidence were crucial to reveal relationships that had gone unnoticed by taxonomists. Characteristics regarded as diagnostic for the classification of Apocynaceae, such as fruit and seed for recognition of tribes, for instance, have been debunked; new interpretations for the morphological evolution of the family have arisen, and together with them, taxonomic rearrangements at different levels. From the beginning of the millennium, the species of the New World have been sampled more often in phylogenetic studies, which made the detection of Neotropical lineages possible, as well as the definition of phylogenetic studies directed specifically to South American groups.

The phylogenetic studies on Asclepiadoideae have boosted taxonomic changes, especially at subtribe and genus levels. Yet, there are some obstacles for a complete understanding of the relationships in the subfamily. The group presents a great morphological diversity where homoplasies are common, making it hard to detect morphological synapomorphies useful for taxon definition. The Neotropical lineages are relatively recent, and except for Cynanchum subg.
Mellichampia, marked by rapid diversification (Rapini et al. 2007). Therefore, finding molecular markers capable of detecting accurate phylogenetic signal to recover the hierarchical structure of these groups is not an easy task. Some inconsistencies have been pointed out by the phylogenetic studies, but a new classification could not always be proposed with certainty, whether due to lack of representatives or to low resolution and/or lack of statistical support for the results (e.g., Silva et al., under review). Thus, it can be said that the taxonomy of Neotropical Asclepiadoideae (and Apocynaceae in general) is "under construction". Every scholar of the group, when defining their object of study, must be aware of the taxonomic instability the group faces and be prepared for its possible implications.

The importance of monographs and taxonomic reviews is undeniable, but the fragility observed in the delimitation of several genera and the urgent need for new taxonomic arrangements in Asclepiadoideae makes the moment inappropriate for extensive reviews. Still, synopses that help identify species and point out its distribution accurately shall guide more detailed studies and represent important stages for new advances in Asclepiadoideae systematics. Small genera (up to 10 species), still confusing and concentrated in Brazil, such as Nephradenia Decne. and Petalostelma E. Fourn., can offer great subjects for Scientific Initiation and Master's course theses. In this sense, Marsdenia offers promising perspectives for mid-term studies. A taxonomic synopsis of the genus for Brazil would be convenient, and phylogenetic studies of intercontinental scope would aid a better understanding of the position of Neotropical species, as well as the relationships among them. On the other hand, other genera, especially Matelea, with wide diversity concentrated in northern South America and complex taxonomy, may be inappropriate for projects with strict deadlines. Biogeographical and phylogeographical studies would also help elucidate Asclepiadoideae systematics, especially when associated with studies on reproductive biology and pollination. This mixture of approaches, if properly applied, could help decode affinities and taxonomic boundaries among close related species or species with questionable delimitation, such as Blepharodon lineare, Minaria cordata (Turcz.) T.U.P. Konno \& Rapini, Oxypetalum insigne (Decne.) Malme, and O. strictum Mart. 


\section{Acknowledgments}

I would like to thank Dr. Ricardo Secco for inviting me to take part in this special issue of the Rodriguésia dedicated to the advances and challenges of taxonomy in Brazil, and for not giving up on the project; Drs André Simões and Pedro Fiaschi, for reviewing the manuscript and tailoring important points in the text and figure; Nathan Smith for reviewing the abstract; Fapesb, for supporting my studies on phylogeny and floristics of Apocynaceae; $\mathrm{CNPq}$, for the productivity scholarship; the Apocynaceae scholars Patrícia L. Ribeiro, Uiara C.S. Silva, Rita Fabiana S. Silva, Leilane N.P. Sampaio, and Rodrigo S. Santos, for the debate and tips on the family taxonomy; and the colleagues Ana Maria Farinaccio, André Simões, Francisco Morales, Ingrid Koch, Jorge Fontella, Mary Endress, Milene Vieira, Sigrid Liede-Schumann, and Sueli Gomes, for taking part at Simpósio de Diversidade e Filogenia de Apocynaceae, which took place during the $60^{\circ}$ Congresso Nacional de Botânica, in Feira de Santana, and was supported by CAPES-DAAD (Cooperação Brasil-Alemanha), CNPq and Fapesp.

\section{References}

APG - The Angiosperm Phylogeny Group III. 2009. An update of the Angiosperm Phylogeny Group classification for the orders and families of flowering plants: APG III. Botanical Journal of the Linnean Society 161: 105-121.

Álvarez, I. \& Wendel, J.F. 2003. Ribosomal ITS sequences and plant phylogenetic inference. Molecular Phylogenetics and Evolution 29: 417-434.

Backlund, A. \& Bremer, K. 1998. To be or not to be principles of classification and monotypic plant families. Taxon 47: 391-400.

Bollwinckel, C.W. 1969. A revision of South American species of Asclepias. PhD Thesis. Southern Illinois University, Illinois. 172p.

Brako, L. \& Zarucchi, J.L. 1993. Catalogue of the flowering plants and gymnosperms of Peru. Monographs in systematic botany. Vol. 45. Missouri Botanical Garden, Saint Louis. 1286p.

Brown, R. 1810. On the Asclepiadeae, a natural order of plants separated from the Apocyneae of Jussieu. Memoirs of the Wernerian Natural History Society 1: 12-78.

Decaisne, J. 1844. Asclepiadaceae. In: Candolle A.P. (ed.). Prodromus systematis naturalis regni vegetabilis. Vol. 8. Fortin, Masson \& Cie, Paris. Pp. 490-665.
Endress, M.E. 2004. Apocynaceae: Brown and now. Telopea 10: 525-541.

Endress, M.E. \& Bruyns, P.V. 2000. A revised classification of Apocynaceae s.l. The Botanical Review 66: 1-56.

Endress M.E.; Liede-Schumann, S. \& Meve, U. 2007. Advances in Apocynaceae: the enlightenment, an introduction. Annals of the Missouri Botanical Garden 94: 259-267.

Endress, M.E. \& Stevens, W.D. 2001. The renaissance of the Apocynaceae $s . l$ : recent advances in systematics, phylogeny, and evolution: Introduction. Annals of the Missouri Botanical Garden 88: 517-522.

Ezcurra, C. 1999. Asclepiadaceae. In: Zuloaga, F.O. \& Morrone, O. (eds.). Catálogo de las plantas vasculares de la Replúbica Argentina. Vol. 2. Missouri Botanical Garden Press, Saint Louis. Pp. 78-98

Farinaccio, M.A. 2007. Sistemática molecular de Oxypetalum R.Br. (Apocynaceae, Asclpeiadoideae). Tese de Doutorado. Universidade de São Paulo, São Paulo. $142 \mathrm{p}+$ anexos.

Feliner, G.N. \& Rosselló, J.A. 2007. Better the devil you know? Guidelines for insightful utilization of nrDNA ITS in species-level evolutionary studies in plants. Molecular Phylogenetics and Evolution 44: 911-919.

Fishbein, M. 2001. Evolutionary innovation and diversification in flower of Asclepiadaceae. Annals of the Missouri Botanical Garden 88: 603-623.

Fontella-Pereira, J. 1977. Revisão taxonômica do gênero Tassadia Descaisne (Asclepiadaceae). Arquivos do Jardim Botânico do Rio de Janeiro 21: 235-392.

Fontella-Pereira, J. (coord.). 2005. Asclepiadaceae. In: Wanderley, M.G.L.; Shepherd, G.J.; Melhem T.S. \& Giulietti A.M. (eds.). Flora fanerogâmica do estado de São Paulo. Vol. 4. FAPESP-RiMa, São Paulo. Pp. 93-156.

Fontella-Pereira, J. \& Ferreira, M.V. 2005. O gênero Macroditassa (Apocynaceae-Asclepiadoideae) no Brasil. Bonplandia 14: 7-34.

Fontella-Pereira, J. \& Marquete, N.F.S. 1973. Estudos em Asclepiadaceae, IV - Blepharodon Descaine. Revista Brasileira de Biologia 33: 77-86.

Fontella-Pereira, J.; Santos, L.B.; Ferreira, M.V.; Goes, M.B.; Carvalho, R.J.P.; Konno T.U.P. \& Mezabarba, V.P. 2003. Asclepiadaceae. In: Cavalcanti, T.B. \& Ramos A.E. (orgs.). Flora do Distrito Federal, Brasil. Vol. 3. EMBRAPA Recursos Genéticos e Biotecnologia, Brasília. Pp. 65-123.

Fontella-Pereira, J. \& Schwarz, E.A. 1981. Estudos em Asclepiadaceae, XXII. Considerações sobre os gêneros Roulinia Decne. (non Brongn) e Rouliniella Vail. Boletim do Museu Botânico Municipal 45: $1-12$.

Fontella-Pereira, J.; Valente, M.C.; Marquete N.F.S. \& Ichaso, C.L.F. 2004. Apocináceas- 
Asclepiadóideas. In: Reitz, R. \& Reis, A. (eds.). Flora ilustrada catarinense. Herbário Barbosa Rodrigues, Itajaí. 250p.

Fournier, E.P.N. 1885. Asclepiadaceae. In: Martius C.F.P. \& Eichler A.W. (eds.). Flora brasiliensis. Typographia Regia, Monachii. Vol. 6, pt. 4. Pp. 189-332; tabs. 50-98.

Goyder, D.J. 1999. The Asclepiadaceae - a fragment of our imagination? In: Timberlake, J. \& Kativu, S. (eds.). African plants: biodiversity, taxonomy and uses. Royal Botanic Gardens, Kew. Pp. 309-317.

Goyder, D.J. 2003. A synopsis of Morrenia Lindl. (Apocynaceae subfam. Asclepiadoideae). Kew Bulletin 58: 713-721.

Goyder, D.J. 2009. A synopsis of Asclepias (Apocynaceae: Asclepiadoideae) in tropical Africa. Kew Bulletin 64: 369-399.

Goyder D.J.; Nicholas, A. \& Liede-Schumann, S. 2007. Phylogenetic relationships in subtribe Asclepiadinae (Apocynaceae: Asclepiadoideae). Annals of the Missouri Botanical Garden 94: 423-434.

Hansen, B.F.; Potgieter, K. \& Stevens, W.D. 2009. Apocynaceae (incl. Asclepiadaceae). In: Daly, D.C. et al. (eds.). Primeiro catálogo da Flora do Acre/First catalogue of Acre Flora: 6-8. PRINTAC/EDUFAC, Rio Branco. 108p.

Hechem, V.; Calviño, C.I. \& Ezcurra, C. 2011. Molecular phylogeny of Diplolepis (ApocynaceaeAsclepiadoideae) and allied genera, and taxonomic implications. Taxon 60: 638-648.

Holm, R.W. 1950. The American species of Sarcostemma R. Br. (Asclepiadaceae). Annals of the Missouri Botanical Garden 37: 477-560.

Juárez-Jaimes, V.; Alvarado-Cárdenas, L.O. \& Villaseñor, J.L. 2007. La familia Apocynaceae sensu lato em México: diversidade y distribución. Revista Mexicana de Biodiversidade 78: 459-482.

Jussieu, A.L. 1789. Genera plantarum. Viduam Herissant, Paris. 498p.

Koch, I. \& Rapini, A. 2011. Apocynaceae. In: Lista de espécies da flora do Brasil. Jardim Botânico do Rio de Janeiro, Rio de Janeiro. Disponível em $<$ http:// floradobrasil.jbrj.gov.br/2011/FB000048>. Acesso em 16 Set 2011.

Konno, T.U.P. 2005. Ditassa R.Br. no Brasil (Asclepiadoideae - Apocynaceae). Tese de Doutorado. Universidade de São Paulo, São Paulo. $239 \mathrm{p}$.

Konno, T.U.P.; Rapini, A.; Goyder, D.J. \& Chase, M.W. 2006. The new genus Minaria (Apocynaceae). Taxon 55: 421-430.

Krings, A.; Thomas, D.T. \& Xiang, Q.-Y. 2008. On the generic circumscription of Gonolobus (Apocynaceae, Asclepiadoideae): evidence from molecules and morphology. Systematic Botany 33: 402-415.
Kunze, H.; Meve, U. \& Liede, S. 1994. Cibirhiza albersiana, a new species of Asclepiadaceae, and establishment of the tribe Fockeeae. Taxon 43: 367-376.

Lahaye, R.; Klackenberg, J.; Källersjö, M.; Campo, E. \& Civeyrel, L. 2007. Phylogenetic relationships between derived Apocynaceae s.l. and within Secamonoideae based on chloroplast sequences. Annals of the Missouri Botanical Garden 94: 376-391.

Leeuwenberg, A.J.M. 1994. Taxa of the Apocynaceae above the genus level. Series of revisions of Apocynaceae XXXVIII. Wageningen Agricultural University Papers 94: 45-60.

Liede, S. 1994. Myth and reality of the subtribe Astephaninae (Decne.) Schumann (Asclepiadaceae). Botanical Journal of the Linnean Society 114: 81-98.

Liede, S. 1996a. Cynanchum - Rhodostegiella Vincetoxicum - Tylophora: new considerations on an old problem. Taxon 45: 193-211.

Liede, S. 1996b. Sarcostemma (Asclepiadaceae) - a controversial generic circumscription reconsidered: morphological evidence. Systematic Botany 21: 31-44.

Liede, S. 1997a. Subtribes and genera of the tribe Asclepiadeae (Apocynaceae, Asclepiadoideae) - a synopsis. Taxon 46: 233-247.

Liede, S. 1997b. American Cynanchum (Asclepiadaceae) - a preliminary infrageneric classification. Novon 7: 172-181.

Liede, S. \& Albers, F. 1994. Tribal disposition of genera in the Asclepiadaceae. Taxon 43: 201-231.

Liede, S. \& Taüber, A. 2000. Sarcostemma R. Br. (Apocynaceae-Asclepiadoideae). A controversial generic circumscription reconsidered: evidence from trnL-trnF spacers. Plant Systematics and Evolution 225: 133-140.

Liede, S. \& Taüber, A. 2002. Circumscription of the genus Cynanchum (Apocynaceae-Asclepiadoideae). Systematic Botany 27: 789-801.

Liede, S.; Taüber, A. \& Schneidt, J. 2002. Molecular considerations in the Tylophorinae K. Schum. (Apocynaceae-Asclepiadoideae). Edinburgh Journal of Botany 59: 377-403.

Liede-Schumann, S. \& Meve, U. 2008. Nomenclatural novelties and one new species in Orthosia (Apocynaceae, Asclepiadoideae). Novon 18: 202-210.

Liede-Schumann, S.; Rapini, A.; Goyder, D.J. \& Chase, M.W. 2005. Phylogenetics of the New World subtribes of Asclepiadeae (ApocynaceaeAsclepiadoideae): Metastelmatinae, Oxypetalinae, and Gonolobinae. Systematic Botany 30: 183-194.

Livshultz, T. 2010. The phylogenetic position of milkweeds (Apocynaceae subfamilies Secamonoideae and Asclepiadoideae): evidence from the nucleus and chloroplast. Taxon 59: 1016-1030. 
Livshultz, T.; Middleton, D.J.; Endress, M.E. \& Williams, J.K. 2007. Phylogeny of Apocynoideae and the APSA clade (Apocynaceae s.l.). Annals of the Missouri Botanical Garden 94: 324-359.

Marquete, N.F.S. 1979. Revisão taxonômica do gênero Barjonia Decne. (Asclepiadaceae). Rodriguésia 31: 7-70

McNeill, J.; Barrie, F.R.; Burdet, H.M.; Demoulin, V.; Hawksworth, D.; Marhold, K.; Nicolson, D.H.; Prado, J.; Silva, P.C.; Skog, J.E.; Wiersema, J.E.H. \& Turland, N.J. 2006. International Code of Botanical Nomenclature (Vienna Code) adopted by the Seventeenth International Botanical Congress Vienna, Austria, July 2005. [Regnum Vegetabile. V. 146.] Ruggell, A.R.G. Gantner Verlag. 568p.

Meve, U. 2002. Species number and progress in asclepiad taxonomy. Kew Bulletin 57: 459-464.

Meve, U. \& Liede, S. 2004 Subtribal division of Ceropegieae (Apocynaceae-Asclepiadoideae). Taxon 53: 61-72.

Mezabarba, V.P.; Goes, M.B.; Rapini, A.; Konno, T.U.P.; Fontella-Pereira, J. \& Goyder, D.J. 2006. Asclepiadaceae. In: Gamarra-Rojas, C.F.L.; Mesquita, A.C.; Mayo, S.; Sother, C.; Barbosa M.R.V. \& Dalcin, E. (eds.). Checklist das plantas do Nordeste. Ministério de Ciências e Tecnologia, Brasília \& CNIP, Recife. (versão 1.5). Pp. : 17-20. Disponível em $<$ http:// www.cnip.org.br/bdpn/checklistNE.pdf $>$. Acesso em 16 Set 2011.

Morillo, G.N. 1976. A revision of Blepharodon (Asclepiadaceae). MSc Thesis. Saint Louis University, Saint Louis. 163p.

Murphy, H. 1986. A revision of the genus Fischeria (Asclepiadaceae). Systematic Botany 11: 229-241.

Nilsson, S.; Endress, M.E. \& Grafström, E. 1993. On the relationship of the Apocynaceae and Periplocaceae. Grana suppl. 2: 3-20.

Potgieter, K. \& Albert, V.A. 2001. Phylogenetic relationships within Apocynaceae s.l. based on $\operatorname{trn} L$ intron and $\operatorname{trn} L-F$ spacer sequences and propagule characters. Annals of the Missouri Botanical Garden 88: 523-549.

Rapini, A., 2000. Asclepiadaceae ou Asclepiadoideae (Apocynaceae)? Conceitos distintos de agrupamento taxonômico. Hoehnea 27: 121-130.

Rapini, A. 2002. Six new species of Ditassa R. Br. from the Espinhaço Range, Brazil, with notes on generic delimitation in Metastelmatinae (Apocynaceae Asclepiadoideae). Kew Bulletin 57: 533-546.

Rapini, A. 2004. Apocynaceae (dogbane and milkweed family). In: Smith, N.; Mori, S.A.; Henderson, A.; Stevenson, D.Wm. \& Head, S.V. (eds.). Flowering plants of the Neotropics. Princeton University Press, Princeton. Pp. 23-26.

Rapini, A. 2006. Apocynaceae. In: Giulietti, A.M.; Conceição, A.A. \& Queiroz, L.P. (eds.). Diversidade e caracterização das fanerógamas do semi-árido brasileiro. In: Giulietti, A.M. \& Queiroz, L.P. (coords.). Instituto do Milênio do Semi-árido. Ministério de Ciências e Tecnologia, Brasília. Vol. 1. Pp. 47-52.

Rapini, A. 2010a. Revisitando as Asclepiadoideae (Apocynaceae) da Cadeia do Espinhaço. Boletim de Botânica da Universidade de São Paulo 28: 97-123.

Rapini, A. 2010b. Asclepiadoideae (Apocynaceae): Espinhaço Range, Minas Gerais and Bahia, Brazil. In: Foster, R.; Phillip, J. \& Watcher, T. (prods.). Rapid color guide \#19, version 3. The Field Museum, Chicago. 14p. Disponível em <http:// fm2.fieldmuseum.org/plantguides/iter_guide. asp type $=$ full\&id $=157 \&$ link $=019 \% 20$ Ascleps. pdf $>$. Acesso em 16 Set 2011.

Rapini, A.; Berg, C. \& Liede-Schumann, S. 2007. Diversification of Asclepiadoideae (Apocynaceae) in the New World. Annals of the Missouri Botanical Garden 94: 407-422.

Rapini, A.; Chase, M.W.; Goyder, D.J. \& Griffiths, J. 2003. Asclepiadeae classification: evaluating the phylogenetic relationships of New World Asclepiadoideae (Apocynaceae). Taxon 52: 33-50.

Rapini, A. \& Fontella-Pereira, J. 2009. Asclepiadoideae (in Apocynaceae). In: Stehmann, J.R.; Forzza, R.C.; Salino, A.; Sobral, M.; Costa, D.P. \& Kamino, L.H.Y. (eds.). Plantas da floresta atlântica. Instituto de Pesquisa Jardim Botânico do Rio de Janeiro, Rio de Janeiro. Pp. 132-140.

Rapini, A. \& Fontella-Pereira, J. 2011. Two new species of Marsdenia R. Br. (Apocynaceae: Asclepiadoideae) from the semi-arid region of Brazil. Kew Bulletin 66: 137-142.

Rapini, A.; Fontella-Pereira, J. \& Goyder, D.J. 2011. Towards a stable generic circumscription in Oxypetalinae (Apocynaceae). Phytotaxa 26: 9-16.

Rapini, A.; Fontella-Pereira, J.; Lamare, E. \& LiedeSchumann, S. 2004. Taxonomy of Peplonia (including Gonioanthela) and a reinterpretation of Orthosieae (Asclepiadoideae, Apocynaceae). Kew Bulletin 59: 531-539.

Rapini, A.; Goyder, D.J.; Konno, T.U.P. \& Farinaccio, M.A. 2005. Progress in asclepiad taxonomy: species number in Brazilian Asclepiadoideae (Apocynaceae) through time. Kew Bulletin 60: 111-115.

Rapini, A.; Koch, I.; Kinoshita, L.S.; Simões, A.O. \& Spina, A.P. 2010a. Apocynaceae. In: Forzza, R.C. et al. (eds.). Catálogo de plantas e fungos do Brasil. Instituto de Pesquisa Jardim Botânico do Rio de Janeiro, Rio de Janeiro. Vol. 1. Pp. 617-644.

Rapini, A.; Koch, I. \& Simões, A.O. 2010c. Rauvolfia anomala, uma nova espécie de Apocynaceae da Chapada dos Guimarães, Mato Grosso, Brasil. Rodriguésia 61: 95-100. 
Rapini, A.; Konno T.U.P. \& Chase, M.W. 2006. Phylogenetics of South American Asclepiadoideae (Apocynaceae). Taxon 55: 119-124.

Rapini, A.; Mello-Silva, R. \& Kawasaki, M.L. 2001. Asclepiadoideae (Apocynaceae) da Cadeia do Espinhaço de Minas Gerais, Brasil. Boletim de Botânica da Universidade de São Paulo 19: 55-169.

Rapini, A.; Mello-Silva R. \& Kawasaki, M.L. 2002. Richness and endemism in Asclepiadoideae (Apocynaceae) from the Espinhaço Range of Minas Gerais, Brazil - a conservationist view. Biodiversity and Conservation 11: 1733-1746.

Rapini, A.; Ribeiro, P.L. \& Silva, U.C.S. 2010b. 667. Hemipogon abietoides (Apocynaceae-Asclepiadoideae). Curtis's Botanical Magazine 27: 1-13.

Rapini, A.; Souza-Silva, R.F. \& Sampaio, L.N.P. 2009. Apocynaceae. In: Giulietti, A.M.; Rapini, A.; Andrade, M.J.G.; Queiroz, L.P. \& Silva J.M.C. (eds.). Catálogo de espécies raras de plantas do Brasil. Conservação Internacional do Brasil, Belo Horizonte; UEFS, Feira de Santana. Pp. 54-64.

Reveal, J.L. \& Chase, M.W. 2011. APG III: bibliographical information and synonymy of Magnoliidae. Phytotaxa 19: 71-134.

Rosatti, T.J. 1989. The genera of suborder Apocynineae (Apocynaceae and Asclepiadaceae) in the southeastern United States. Journal of the Arnold Arboretum 70: 307-401; 443-514.

Safwat, F.M. 1962. The floral morphology of Secamone and the evolution of the pollinating apparatus in Asclepiadaceae. Annals of the Missouri Botanical Garden 49: 95-29.

Schlechter, R. 1905. Periplocaceae \& Asclepiadaceae. In: Schumann, K. \& Lauterbach, K. (eds.). Flora der Deutschen Schutzgebiete in der Südsee. Bornträeger, Leipzig. Pp. 351-369.

Schumann, K. 1895. Asclepiadaceae. In: Engler, H.G.A. \& Prantl, K.A.E. (eds.). Die Natürlichen Pflanzenfamilien. Wilhelm Engelmann, Leipzig. Vol. 4, pt. 2. Pp. 189-306.

Schwarz, E.A. \& Fontella-Pereira, J. 1995. O gênero Jobinia Fournier (Asclepiadaceae) no Brasil. Acta Biológica Paranaense 24: 49-157.

Sennblad, B. \& Bremer, B. 1996. The familial and subfamilial relationships of Apocynaceae and Asclepiadaceae evaluated with $r b c L$ data. Plant Systematics and Evolution 202: 153-176.

Sennblad, B. \& Bremer, B. 2000. Is there a justification for differential a priori weighting in coding sequences? A case study from $r b c \mathrm{~L}$ and Apocynaceae s.l. Systematic Biology 49: 101-113.

Sennblad, B. \& Bremer, B. 2002. Classification of Apocynaceae s.l. according to a new approach combining Linnaean and phylogenetic taxonomy. Systematic Biology 51: 389-409.

Sennblad, B.; Endress M.E. \& Bremer, B. 1998. Morphology and molecular data in phylogenetic fraternity: the tribe Wrightieae (Apocynaceae) revisited. American Journal of Botany 85: 11431158.

Silva, U.C.S. 2008. Sistemática molecular de Metastelmatinae (Asclepiadoideae, Apocynaceae), com ênfase em cinco espécies endêmicas da Chapada Diamantina, Bahia. Monografia de Conclusão do Curso de Ciências Biológicas. Universidade Estadual de Feira de Santana, Feira de Santana. 49p.

Silva, U.C.S. 2010. Estudos filogenéticos moleculares em Metastelmatinae (Asclepiadoideae, Apocynaceae). Dissertação de Mestrado. Universidade Estadual de Feira de Santana, Feira de Santana. 75p.

Simões,A.O.; Endress, M.E. \& Conti, E. 2010. Systematics and character evolution of Tabernaemontaneae (Apocynaceae, Rauvolfioideae) based on molecular and morphological evidence. Taxon 59: 772-790.

Simões, A.O.; Endress, M.E.; van der Niet, T.; Conti, E. \& Kinoshita L.S. 2004. Tribal and intergeneric relationships of Mesechiteae (Apocynaceae, Apocynoideae): evidence from three noncoding plastid DNA regions and morphology. American Journal of Botany 91: 1409-1418.

Simões, A.O.; Endress, M.E.; van der Niet, T.; Kinoshita. L.S. \& Conti, E. 2006. Is Mandevilla (Apocynaceae, Mesechiteae) monophyletic? Evidence from five plastid DNA loci and morphology. Annals of the Missouri Botanical Garden 93: 565-591.

Simões, A.O.; Livshultz, T.; Conti, E. \& Endress, M.E. 2007. Phylogeny and systematics of the Rauvolfioideae (Apocynaceae) based on molecular and morphological evidence. Annals of the Missouri Botanical Garden 94: 268-297.

Sundell, E. 1981. The New World species of Cynanchum subgenus Mellichampia (Asclepiadaceae). Evolutionary Monographs 5: 1-63.

Wanntorp, H.-E. 1988. The genus Microloma (Asclepiadaceae). Opera Botanica 98: 1-69.

Woodson Jr., R.E. 1933. Studies in the Apocynaceae IV. The American genera of Echitoideae. Annals of the Missouri Botanical Garden 22: 153-306.

Woodson Jr., R.E. 1941. The North American Asclepiadaceae. Annals of the Missouri Botanical Garden 28: 193-244.

Woodson Jr., R.E. 1954. The North American species of Asclepias L. Annals of the Missouri Botanical Garden 41:1-211. 